\title{
Burkholderia gladioli
}

National Cancer Institute

\section{Source}

National Cancer Institute. Burkholderia gladioli. NCI Thesaurus. Code C86225.

A species of aerobic, Gram-negative, rod shaped bacteria assigned to the phylum

Proteobacteria. This species is motile, indole and oxidase negative, catalase positive, negative for lysine decarboxylation, and does not reduce nitrate. B. gladioli is found on the gladiolus plant where it is pathogenic, causes vegetation to decay, and is pathogenic to humans. 